\title{
Narrator profile in translation: Work-in-progress for a semi- automatic analysis of narratorial dialogistic and attitudinal positioning in translated fiction
}

\author{
Alexandra Assis Rosa \\ University of Lisbon
}

This paper presents work-in-progress for the development of a semiautomatic methodology for the analysis of shifts in narrator profile in translated fiction. Such a methodology is developed for a comparative quantitative analysis of electronic source and target texts organized in a parallel corpus. The first and main part of this paper presents the theoretical motivation for the organization of two systems of categories focusing on the relationship between the two discursive centres involved in reported speech - narrator and character (but also quoter and quotee in other text types) - by developing the proposals of dialogistic/intertextual and attitudinal positioning in Appraisal Theory. The second part of this paper analyses a selection of examples illustrative of such categories, and presents and comments the results of the comparative quantitative analysis of Charles Dickens's Oliver Twist and eight European Portuguese translations for juvenile and adult readerships. This comparative analysis proves the methodology operative and shows evidence of two tendencies: 'levelling-out' and 'explicitation', which, although elsewhere identified as translational universals, may here be identified as norms because they correlate with the independent variable target readership. The purpose of developing this methodology is to help describe the way interlingual translation may transform narrator profile as well as contribute to the formulation of translational norms.

\section{Introduction: methodological issues}

This article presents work-in-progress for the development of a semiautomatic methodology for the analysis of shifts in narrator profile in translated fiction. It is theory-motivated since it presents a model for the study of translational norms, based on the assumption (imported from Systemic Functional Grammar, Critical Linguistics and Pragmatics) that linguistictextual forms both create and express context, by encoding communicative meaning, pragmatic and sociosemiotic value (Hatim and Mason 1990). The methodology presented here for the semi-automatic analysis of forms expressing tenor in (translated) fiction also draws on Corpus Linguistics, Corpus-Based Descriptive Translation Studies and Discourse Analysis. This research is also data-motivated because it has been developed both based on and for a comparative quantitative analysis of an electronic parallel corpus 
of Dickensian Source Texts and their translations. ${ }^{1}$ As Toury suggested (1995: 38): "The normal progression of a study is thus helical, then, rather than linear: there will always remain something to go back to and discover, with the concomitant need for more (or more elaborate) explanations." The progression of this study was also helical rather than linear in that it was deeply motivated by the set of data used to test the model and the methodology in search of more accurate descriptive statements, which, in turn, raise the aspiration for enhanced explanatory capacity.

\section{Tenor in translated fiction}

Previous research (Rosa 2000, 2003, 2007) has focused mainly on tenor or interpersonal relations in fictional dialogue and its translation assuming that texts function as records of communicative transactions. The purpose of analysing fiction and its translation as communicative transaction made it necessary (1) to identify participants in translated narrative fiction, (2) to organize them in pairs of addresser-receiver/addressee and (3) to locate them at different narrative and enunciative levels. This endeavour also resulted in the hierarchical model represented in the following Figure, which was the first step to identify different sets of textual-linguistic features encoding tenor for each level identified in the model.

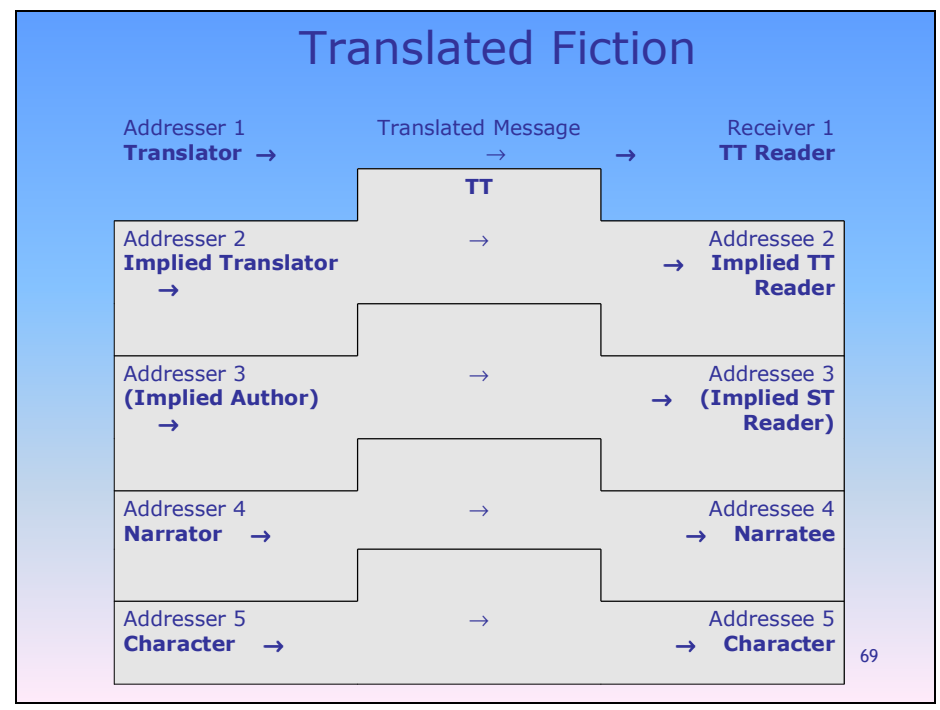

Figure 1: Translated fiction as communicative transaction (Rosa 2003: 254)

One of the additions to previous research in TS is the fact that this model organizes participants at different enunciative and narrative levels instead of organizing them in linear succession (see Hermans 1996; Schiavi 1996; 
O'Sullivan 2003), since it assumes that translated fiction functions pragmatically as a hierarchy of voices orchestrated by the translator as addresser of the Target Text. ${ }^{2}$ The model in Figure 1 starts at the lowest enunciative/narrative level, where a character says something to another character, not only because the narrator intentionally reports this transaction to a narratee, and the implied ST author conveys their transaction to the implied ST reader, but also because the Implied Translator, in turn, conveys all these transactions to the implied TT Reader. In this model, the asymmetry of power relationships in translated fiction is stressed: addressers have more power than addressees and upper level participants have more power than lower level participants, whose communicative transactions are relayed. The second addition to previous research in TS, and of particular importance, is the definition of the Implied Translator as an intratextual participant, whose profile is identifiable for each translated text and here equated with translational decisions regarding the maintenance or shift of both the profiles and the relationships of participants belonging to all subordinate levels. It is our contention that the actual power possessed by addressers located in upper levels may be either explicitly expressed or camouflaged, and that this will be revealed by the analysis of textual-linguistic and narrative feature patterning.

Therefore, to analyse translation as product, it is assumed that the interpersonal relations that obtain between each pair of intratextual participants within the same level and also among participants belonging to different levels are encoded in the text by a set of textual-linguistic and narrative features, and are as such subject to translational shifts. The aim of our ongoing research so far (part of which is presented in this article) has been to identify correlations between textual-linguistic features and functions applicable to each of the enunciative/narrative levels presented in Figure 1 so as to better understand and describe macrostructural shifts that the translation of fiction seems to involve, namely shifts affecting the profiles of participants in translated narrative fiction. ${ }^{3}$

This report presents research developments that make the initial model more sophisticated by focusing on additional textual-linguistic and narrative features that may prove relevant for the analysis of narratornarratee transaction (Addresser and Addressee 4) and its translation. Following Seymour Chatman's statement that "[i]t is less important to categorize types of narrators than to identify the features that mark their degree of audibility" (Chatman 1978: 196), the model already developed for the analysis of the communicative transaction between narrator and narratee identifies intratextual features which profile the narrator's conspicuousness or "degree of audibility" in each sentence in both ST and TT. This model considers (1) the proportion of sentences that report dialogue vs. those that do not and so conspicuously belong to the narrator's voice only, as well as (2) the most frequent categories of reported speech used to convey dialogue. ${ }^{4}$ The present study further includes (3) the most conspicuous presence of the narrator in the textual surface by way of self-reference to him- 
self/herself as an "I" that sometimes mentions its narrative function; and (4) the conspicuousness of the narrator's evaluation mainly regarding the characters whose speech is quoted.

Considerations (1) and (3) are quite straightforward. Once orthographical sentences in the corpus (taken as units for analysis) are labelled as dialogue reporting vs. not dialogue reporting and including vs. not including forms of self-reference by the narrator, the quantitative results are deemed to reveal a particular fictional style regarding narratorial conspicuousness and narrator-narratee transaction.

As for (2), since the narrator's voice is heard/read not only in narrative sentences but also in those sentences that report speech, a set of categories of reported speech were identified and organized in terms of the degree of interference or audibility of the narrator's voice. The five categories chosen were: Narrative Report of Speech Acts, Indirect Speech, Free Indirect Speech, Direct Speech and Free Direct Speech. ${ }^{5}$ The choice of this set of five categories was the result of a necessary balance between descriptive sophistication and the need to establish distinctions that are as clear and operative as possible so as to enable a semi-automatic analysis of an electronic parallel corpus. ${ }^{6}$ These five categories of speech report are a set of discursive tools, and the proportion of these categories in narrative fiction may be deemed to generate a fictional style. So, their analysis was expected to reveal the degree of interference of the narrator's voice in reported speech. These categories were organized from the apparent total control of the narrator to the apparent least control of report, from Narrative Report of Speech Acts, through Indirect Speech, Free Indirect Speech, Direct Speech and Free Direct Speech, and later grouped so as to allow for a binary analysis.

Table 1: Binary analysis of reported speech categories

\begin{tabular}{|c|c|}
\hline $\begin{array}{c}\text { Greater conspicuousness of } \\
\text { narratorial voice }\end{array}$ & $\begin{array}{c}\text { Lesser conspicuousness of } \\
\text { narratorial voice }\end{array}$ \\
Narrative Report of Speech Acts & Direct Speech (DS) \\
(NRSA) & Free Direct Speech (FDS) \\
Indirect Speech (IS) & \\
Free Indirect Speech (FIS) & \\
\hline
\end{tabular}

The left column in Table 1 groups together the categories of reported speech that confer greater conspicuousness or audibility on the narratorial voice, in which the narrator's power over reported speech by characters is more noticeable; the right column includes the categories that render the narrator's voice less audible and that camouflage narratorial power by conferring greater autonomy on the characters' voices, whose speech is reported. 
The most pervasive pattern in translation does not seem to be the maintenance of ST features but the opposite: shifts. As research has already suggested (van Leuven-Zwart 1989, 1990; Gullin 1998) if microstructural features are changed through translation, as a consequence, macrostructural levels are affected too; and narrator profile is particularly prone to shifts. Therefore, the most persistent pattern in the translation of narrative fiction is expected to be a transformation of participant profiles in general and of the narrator profile in particular, brought about by an accumulation of micro-structural shifts caused by translational procedures. As used here, the word 'transformation' may be deemed too strong. However, the examples below may account for this lexical choice as well as for the wish to account for such shifts in narrator profile in a systematic and quantitative way to find out more exactly how widespread they are.

Regarding consideration (4) the conspicuousness of narratorial evaluation in the Dickensian source texts included in the parallel corpus, the narrator's evaluation in reported dialogue is present in three main forms: (1) in the choice of verba dicendi or verbs of saying; (2) in adjuncts that express manner; and (3) in the forms of reference to characters.

Examples 1 and 2 illustrate the use of the most frequent verb of saying in the ST: "said". In the target texts, this fairly neutral verb of saying is replaced by "exclaimed" or "ordered". The corresponding Portuguese verbs of saying used, "exclamou" and "ordenou", are more informative, identify the speech act, and in the case of "ordered" ("ordenou") may be said to carry an implicit negative evaluation, which results from the narrator's identification of a direct directive speech act that corresponds to an unabashed expression (and reinforcement) of an asymmetrical power relation: ${ }^{7}$

(1) $<$ OT S208 $><$ p84 $>$ The board were sitting in solemn conclave, when Mr. Bumble rushed into the room in great excitement, and addressing the gentleman in the high chair, said 'Mr. Limbkins, I beg your pardon, sir!

$<O T 7$ S183> O conselho celebrava uma sessão solene, quando o senhor Bumble se precipitou desvairado na sala e, dirigindo-se ao presidente, exclamou: - Peço-lhe perdão, senhor Limbkins.

[The board were celebrating a solemn session, when Mr. Bumble rushed into the room highly upset, and addressing the president, exclaimed: "I beg your pardon, Mr. Limbkins."]

(2) $<$ OT S475><p224> 'Then come with me,' said Mrs. Sowerberry: (...)

$<$ OT14 S492> <p229> -Então vem comigo - ordenou a Sra. Sowerberry.

["Then come with me," ordered Mrs. Sowerberry.] 
$<O T 16$ S235> <p114>-Vem comigo - ordenou-lhe a senhora Sowerberry...

["Come with me," ordered Mrs. Sowerberry. (Our emphasis)]

In Example 3, we read that the doctor says something to Oliver's mother "with more kindness than might have been expected of him". In the first TT example, this kindness that is unexpected of him, as an individual, is turned into: "with more sweetness than might have been expected from his profession' ("com mais doçura do que se poderia esperar da sua profissão"), the presupposition being that no member of the medical profession can be expected to be kind. In the second TT example, the doctor's kindness turns into indifference when we read 'turning his face away with indifference' ("voltando o rosto com indiferença"). In other words, a positive and explicit evaluation present in the ST becomes negative and explicit in this TT:

(3) <OT S10> As the young woman spoke, he rose, and advancing to the bed's head, said, with more kindness than might have been expected of him: 'Oh, you must not talk about dying yet.

$<O T 7$ S12> Ouvindo a voz da jovem, levantou-se e, aproximando-se do leito, disse com mais doçura do que se poderia esperar da sua profissão: -Não deve falar agora em morrer.

[Hearing the young woman's voice, he rose and advancing towards the bed said with more sweetness than might have been expected of his profession: "You should not talk about dying now."]

$<0 T 9$ S6 > <p4> -Vamos, anime-se -respondeu o cirurgião, voltando o rosto com indiferença.

["Come, cheer up," the surgeon replied, turning his face away with indifference. (Our emphasis)]

The narrator of Oliver Twist very often resorts to implicature ${ }^{8}$ and example 4 starts with an excessively positive form of reference to a character, only to make a volte-face at the end of the sentence where the clause introduced by the additive conjunction takes the reader by surprise: "The elderly female was a woman of wisdom and experience; she knew what was good for children; and she had a very accurate perception of what was good for herself." (our emphasis): 
(4) $<$ OT S47> The elderly female was a woman of wisdom and experience; she knew what was good for children; and she had a very accurate perception of what was good for herself.

<OT6 S43> A velha era cheia de sabedoria e de experiência; sabia o que convinha às crianças, e sabia também perfeitamente o que lhe convinha a ela (...)

[The old woman was full of wisdom and experience; she knew what was good for children and she also perfectly knew what was good for her.]

$<O T 7$ S42> A velha era cheia de manha e de experiência. [The old woman was full of cunning and experience.]

$<$ OT9 S32> <p17> (...) a administração estava a cargo de uma mulher de poucos escrúpulos, que reservava para si a maior parte das pensões concedidas aos asilados.

[In charge of the administration was a woman of little scruples, who kept for herself most of the pension granted the asylum inmates.]

$<O T 17$ S51> Essa mulher, mesquinha e ruim, preferia ficar com o dinheiro para si e deixar as crianças passar fome.

[That mean and nasty woman would rather keep the money for herself and let the children starve.(Our emphasis)]

In the four translated excerpts presented here, we see the implicature of this form of reference made explicit from the start, and the elderly female becomes 'the old woman' or even 'the hag'. Consequently, if we organize the Portuguese versions in a cline, we read: "the old woman full of wisdom and experience' ("A velha cheia de sabedoria e experiência"), "the old woman full of cunning and experience' ("A velha cheia de manha e de experiência"), 'a woman of little scruples' ("Uma mulher de poucos escrúpulos") or 'that mean and nasty woman' ("Essa mulher mesquinha e ruim."). In these examples, explicitation of implicature transforms implicit negative evaluation into an explicit negative stance. It is our contention that these shifts of positive and negative stance, implicit and explicit stance contribute to the transformation of both narrator and narratee profile. Presuppositions inferred are that the implied reader is not expected to be able to grasp implied meaning that is transferred to the TT as explicit evaluation, through explicitation. 


\section{Theoretical framework: narratorial evaluation}

In order to account for such instances of narratorial evaluation by means of a systematic quantitative analysis, we started with Genette's notion of testimonial function, that is defined as oriented towards the narrator (by association with Jakobson's well-known definition of the emotive function) and is present whenever the narrator expresses an affective, moral or intellectual stance towards the story, or, in this case, towards the characters or the speech s/he reports (Genette 1972).

For the purpose of a more sophisticated description of instances such as the examples just mentioned, we also imported a set of categories created by Appraisal Theory. In the last fifteen years, Appraisal Theory has been developed within the framework of Systemic-Functional Grammar by a group of researchers led by James Martin and Peter R. White. Appraisal Theory focuses on a descriptive study of evaluative language use, that is, of the way language is used to evaluate or negotiate stance and interpersonal relationships, mainly by the use of an interpersonal system of evaluative lexis.

Appraisal encompasses: attitudinal positioning and dialogistic positioning or intertextual positioning, the latter two of which are related to Bakhtinian dialogism and heteroglossia. As we read in White's Guide to Appraisal (2001: 2):

The term 'Appraisal' is used as a cover-all term to encompass all evaluative uses of language, including those by which speakers/writers adopt particular value positions or stances and by which they negotiate these stances with either actual or potential respondents.

Under dialogistic or intertextual positioning, White comprehends (2001: 6):

uses of language by which writers/speakers adopt evaluative positions towards what they represent as the views and statements of other speakers or writers, towards the propositions they represent as deriving from outside sources. At its most basic, intertextual positioning is brought into play when a writer/speaker chooses to quote or reference the words or thoughts of another.

This type of analysis focuses on the relationship between the two discursive centres involved in reported speech (the narrator and the character whose words are quoted), which has already been suggested to be expressed by the percentage of dialogue vs. non-dialogue sentences in each narrative text as well as by the most frequent categories of reported speech chosen to depict dialogue (Rosa 2003, 2007). 
However, it is attitudinal positioning that is central to this investigation for the purpose of analysing the testimonial function. It is meant to encompass the use of "meanings by which writers/speakers indicate either a positive or negative assessment of people, places, things, happenings and states of affairs" (White 2001: 2) and will be used to base the analysis of the narrator's evaluation of the story's characters.

Regarding attitudinal positioning - and so as to keep the analysis as simple as possible, irrespective of its being emotional, ethical or aesthetic, as suggested by Appraisal Theory - we only considered whether (1) the narrator's stance was evaluative or neutral; (2) positive (Endorsement) or negative (Disendorsement); and (3) explicitly marked by the use of euphoric or disphoric lexis or implicitly expressed through implicature.

To sum up, the first part of this article has presented the theoretical and data motivation for the organization of two systems of categories focusing on the relationship between the two discursive centres involved in reported speech, narrator and character (quoter and quotee in other text types).

The first system organizes in a cline a set of descriptive categories of reported speech considered expressive of different power relations towards what the narrator represents as speech by other speakers, and thus of different types of dialogistic or intertextual positioning. It includes:

- the proportion of dialogue vs. non-dialogue reporting sentences in fiction, as expressive of the power relations that the narrator establishes with characters quoted, with the narratee and ultimately with the reader,

- the presence or absence of forms of self-reference by the narrator and

- two categories of forms of reported speech considered expressive of different power relations towards what the narrator represents as speech by other speakers.

The second system organizes categories expressive of the narrator's positive or negative evaluation of characters, and thus of attitudinal positioning, also as proposed by Appraisal Theory (White 2001). Therefore, the second system organizes categories expressive of the narrator's

- $\quad$ evaluative vs. neutral stance,

- $\quad$ positive or negative evaluation mainly of characters that intervene in the story, as well as

- the classification of this evaluation as explicit or implicit.

The second part of this paper presents and comments on the results of the comparative quantitative analysis of Charles Dickens's Oliver Twist and eight European Portuguese translations for juvenile and adult readerships. ${ }^{10}$ The aim of developing this methodology for a semi-automatic quantitative and qualitative analysis of translated narrative fiction is to describe how 
interlingual translation may transform the narrator profile in terms of dialogistic/intertextual and attitudinal positioning as well as to contribute to the description of translational regularities by correlating them with contextual variables (such as implied readership), the ultimate purpose being the formulation of translational norms (Toury 1995).

\section{The parallel corpus}

So as to set up a parallel corpus including samples of approximately 500 sentences, the first four chapters of Oliver Twist were selected for the nontranslated subcorpus; the translated subcorpus includes the corresponding samples of eight target texts published after the 1940s (see Table 2).

Table 2: Parallel corpus

\begin{tabular}{|c|c|c|c|}
\hline & Corpus & No. Sentences & $\begin{array}{c}\text { TT } \\
\text { Condensation }^{11} \\
\end{array}$ \\
\hline & & & \\
\hline & Source Text: OT (chapters 1-4) & 480 & \\
\hline & & & \\
\hline & Target Texts: & & \\
\hline 1 & OT6 (1942; adult reader) & 430 & $89.58 \%$ \\
\hline 2 & OT7 (1952; adult reader) & 426 & $88.75 \%$ \\
\hline 3 & $\begin{array}{l}\text { OT8 (1968; teenage or child } \\
\text { reader; condensation) }\end{array}$ & 76 & $15.83 \%$ \\
\hline 4 & $\begin{array}{l}\text { OT9 (1972; teenage reader; } \\
\text { adaptation) }\end{array}$ & 274 & $57.08 \%$ \\
\hline 5 & $\begin{array}{l}\text { OT13 (1980; adult or teenage } \\
\text { reader) }\end{array}$ & 401 & $83.54 \%$ \\
\hline 6 & OT14 (1981; adult reader) & 498 & $103.75 \%$ \\
\hline 7 & OT16 (1988; teenage reader) & 238 & $49.58 \%$ \\
\hline 8 & $\begin{array}{l}\text { OT17 (1993; teenage or child } \\
\text { reader) }\end{array}$ & 188 & $39.17 \%$ \\
\hline & $\begin{array}{l}\text { Total no. of sentences in trans- } \\
\text { lated subcorpus }\end{array}$ & 2531 & \\
\hline
\end{tabular}

The main contextual independent variable selected for this study was intended readership. As shown in Table 2 above, the translated subcorpus includes four texts for an adult readership (1942, 1952, 1980 and 1981) and four texts for teenagers or children (1968, 1972, 1988 and 1993). The chronological scope selected, resulted from the fact that - considering all 17 textually different translations published in European Portuguese (18761993) - it is only in the second half of the $20^{\text {th }}$ century that Oliver Twist was 
translated for teenagers and children, and from the sixties onwards mainly retranslated for this younger readership.

\section{Narrative vs. dialogue reporting sentences}

Let us explore the distinction we expect to find encoded in the TT as a correlate to the contextual independent variable, intended readership, by comparing the quantitative results of the semi-automatic analysis of TT published for adults against those of TT translated for teenagers or children.

Table 3: narrative vs. dialogue sentences (adult readership and teenage/child readership)

\begin{tabular}{|c|c|c|c|c|c|}
\hline & & \multicolumn{2}{|c|}{$\%$ Narrative } & \multicolumn{2}{|c|}{ \% Dialogue } \\
\hline ST & & \multicolumn{2}{|c|}{43} & \multicolumn{2}{|c|}{57} \\
\hline \multirow{4}{*}{$\begin{array}{r}\mathrm{TT}: \\
\text { adult reader }\end{array}$} & 1942 & 35.6 & \multirow[t]{4}{*}{40.5} & 64.4 & \multirow[t]{4}{*}{$\mathbf{5 9 . 5}$} \\
\hline & 1952 & 47.3 & & 52.7 & \\
\hline & 1980 & 37.6 & & 62.4 & \\
\hline & 1981 & 41.5 & & 58.5 & \\
\hline \multirow{4}{*}{$\begin{array}{r}\text { TT: } \\
\text { teenage/child } \\
\text { reader }\end{array}$} & 1968 & 48.7 & \multirow[t]{4}{*}{46.5} & 51.3 & \multirow[t]{4}{*}{53.5} \\
\hline & 1972 & 34.9 & & 65.1 & \\
\hline & 1988 & 46.63 & & 53.36 & \\
\hline & 1993 & 55.9 & & 44.1 & \\
\hline
\end{tabular}

Table 3 shows the ratios between dialogue vs. non-dialogue sentences. In the first four chapters of Oliver Twist, $57 \%$ of sentences report the characters' speech and depict their dialogue. A smaller percentage of $43 \%$ can be identified as belonging to the narrator's voice. All TT for adults, except for one of 1952 increase by an average of 3\% the predominance of dialogue reporting sentences already present in the ST (57\%), and in this way contribute to making the narrator's voice quantitatively less audible than in the ST. However, as also shown in Table 3, all TT for teenagers and children, except the 1972 version, decrease the predominance of dialogue reporting sentences by an average $4 \%$, and so make the narrator's voice, power and control more visible.

This proportion seems to be pertinent and operative, as it reveals an opposite tendency in both subcorpora: in TT for adult readers the narrator's voice is heard less, since dialogue reporting sentences are more predominant than they already were in the ST; in TT for teenage/child readers the narrator's voice is heard more than in the source text. It is possible that the higher degree of condensation shown by TT for teenage/child readers (Table 2) was obtained by omitting dialogue sentences. Only an analysis of an aligned parallel corpus will tell. Nevertheless, the comparative quantitative analysis shows that the narratorial power of giving/not giving the floor is more strongly felt in TT for teenage/child reader. Moreover, the narrative 
vs. dialogue reporting sentences ratio present in the Source Text $(57 / 43,14)$ is reduced in the TT for teenage/child reader $(53.5 / 46.5,7)$ which may be related to a "levelling-out" universal, whereas it increases in TT for adults $(59.5 / 40.5,19)$. Therefore, TT for adults decrease the conspicuousness of narratorial power and control as shown by the number of sentences attributed to the narrator's voice. This is contrary to a general levelling-out tendency and may be contextually motivated by the influence of modernist narrative techniques upon literary and translational norms in $20^{\text {th }}$ century Portugal. The greater value attached to showing instead of telling, by means of covert or transparent narration (Chatman 1978: 254), may motivate shifts in the modern translations of the $19^{\text {th }}$ century Dickensian narrator profile, which seem to imply a translator who presupposes a lower level of tolerance to a domineering narrator voice among $20^{\text {th }}$ century adult readers.

\section{Presence vs. absence of forms of self-reference}

As to the presence or absence of forms of self-reference to the narrator using first person markers, all four target texts translated for adults maintain the low degree of conspicuous presence of the narrator that refers to himself; all target texts translated for teenagers or children, except for the 1972 text, exclude each and every sentence in which the narrator is most conspicuous by using forms of self-reference. Therefore, the I-presence of the narrator is different in both subcorpora analysed: TT for adults show a predominant slight decrease in the number of sentences in which the narrator's voice is most conspicuously heard through forms of selfreference, whereas TT for teenagers or children show a predominant tendency to abolish such sentences.

Table 4: presence vs. absence of forms of self-reference (adult readership and teenage/child readership)

\begin{tabular}{|c|c|c|c|c|c|}
\hline & & \multicolumn{2}{|c|}{$\%$ I-Present } & \multicolumn{2}{|c|}{$\%$ I-Absent } \\
\hline ST & & \multicolumn{2}{|c|}{1.3} & \multicolumn{2}{|c|}{98.7} \\
\hline \multirow{4}{*}{$\begin{array}{r}\text { TT: } \\
\text { adult reader }\end{array}$} & 1942 & 1.2 & \multirow[t]{4}{*}{1.3} & 98.8 & \multirow[t]{4}{*}{98.7} \\
\hline & 1952 & 1.7 & & 98.3 & \\
\hline & 1980 & 1.1 & & 98.9 & \\
\hline & 1981 & 1.1 & & 98.9 & \\
\hline \multirow{4}{*}{$\begin{array}{r}\text { TT: tee- } \\
\text { nage/child } \\
\text { reader }\end{array}$} & 1968 & 0 & \multirow[t]{4}{*}{0.2} & 100 & \multirow[t]{4}{*}{99.8} \\
\hline & 1972 & 0.6 & & 99.4 & \\
\hline & 1988 & 0 & & 100 & \\
\hline & 1993 & 0 & & 100 & \\
\hline
\end{tabular}

This tendency contrasts with the one regarding narrative vs. dialogue sentences because the narrator's self-reference is more conspicuous in TT for adults than in TT for teenagers and children, where it is nearly absent. 
This omission of forms of self-reference in the TTs for teenagers or children, which also show a high degree of condensation, might be related to the fact that such forms may be ambiguous when read out loud by parents to children who cannot read.

\section{Reported speech categories}

Moving on to the binary analysis of reported speech categories, results show that the ST mainly contains forms that confer more autonomy to the characters' speech and the narrator's voice, power and interference is less audible (92\%). This is indeed a characteristic of Dickensian fiction in which the narrator mainly resorts to direct speech to report dialogue between characters.

Table 5: Forms of speech report (adult readership and teenage/child readership)

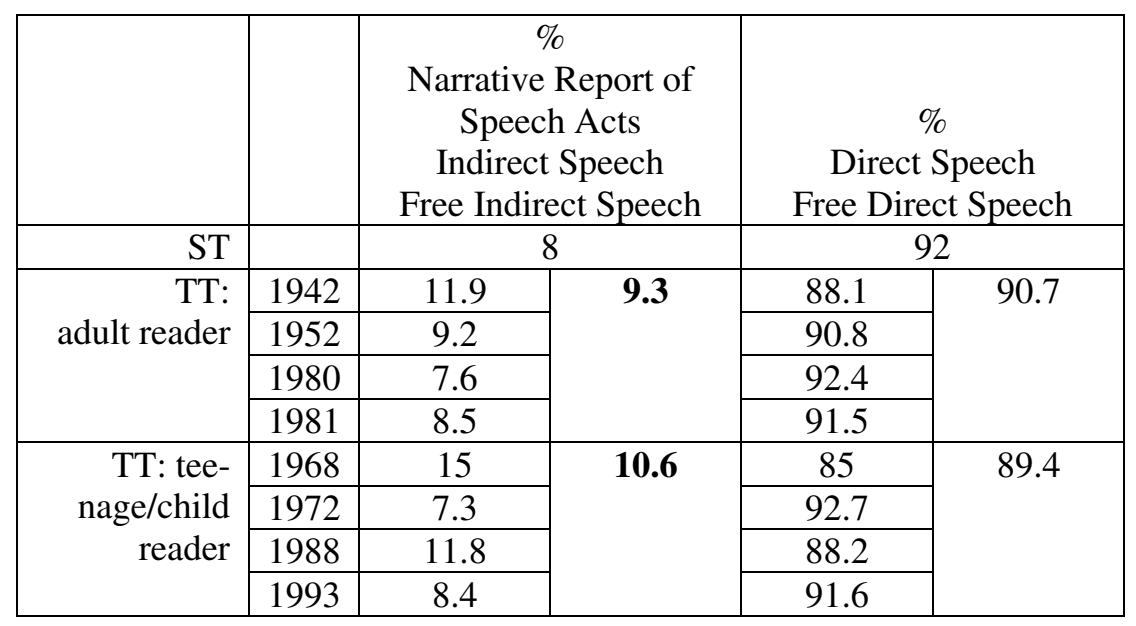

When we compare the ST percentages with those of the TTs we understand that the prominence given to forms of reported speech that show less narratorial control is maintained, although with fluctuations. On average it decreases only $1 \%$ in TTs for adults and 3\% in TTs for teenagers or children (ST: 92\%; TT adults: 91\%; TT teenagers: 89\%). Therefore, TTs for adults as well as those for children and teenagers show a tendency to slightly increase forms of reported speech that give more prominence to the narrator's control and power. As expected, in TTs for children and teenagers this tendency is stronger and their reading, thus, seems to be more controlled by the narrator's voice. This yields a more powerful narrator profile and implies a reader who is presupposed to be less competent and, therefore, needs stronger guidance by the narrator's voice. ${ }^{12}$ 


\section{Attitudinal positioning: evaluative vs. neutral stance}

If we consider the percentage of sentences that mark the evaluative stance of the narrator against those from which it is absent, there is an overall tendency in the TTs to maintain the prominence that the opinionated Dickensian narrator has. However, all TTs but one for adults (published 1981) decrease the narrator's evaluative stance. A predominant increase of the narrator's neutrality is, therefore, also noticeable here, thereby raising the question whether this may be attributed to a levelling-out tendency (universal) or to literary norms that might influence this general tendency to decrease the conspicuousness of the evaluative stance of the Dickensian narrator in translations produced in the second half of the $20^{\text {th }}$ century (norm).

Table 6: Attitudinal positioning: evaluative vs. neutral stance (adult readership and teenage/child readership)

\begin{tabular}{|r|c|c|c|c|c|}
\hline & & \multicolumn{2}{|c|}{ \% Evaluative Stance } & \multicolumn{2}{|c|}{ \% Neutral Stance } \\
\hline ST & & \multicolumn{2}{|c|}{65.4} & \multicolumn{2}{|c|}{34.6} \\
\hline TT: & 1942 & 58.8 & \multirow{2}{*}{61.2} & 41.2 & \multirow{2}{*}{38.8} \\
\cline { 2 - 3 } & 1952 & 60.8 & & 39.2 & \\
\cline { 2 - 3 } adult reader & 1980 & 57.1 & & 42.9 & \\
\cline { 2 - 3 } & 1981 & 68.1 & & \multirow{2}{*}{44.4} \\
\hline TT: tee- & 1968 & 57.6 & \multirow{2}{*}{55.6} & 42.4 & \\
\cline { 2 - 3 } $\begin{array}{r}\text { nage/child } \\
\text { reader }\end{array}$ & 1972 & 51.7 & & 48.3 & \\
\cline { 2 - 3 } & 1988 & 51.9 & & 48.1 & \\
\cline { 2 - 3 } & 1993 & 61.3 & & 38.7 & \\
\hline
\end{tabular}

When we move on to consider a comparative analysis of the two TT subcorpora for different readerships, the results reveal an average decrease in the narrator's evaluative stance by $4 \%$ in the subcorpus for adults and by almost $10 \%$ in the subcorpus for teenagers. Therefore, this overall tendency to decrease the narrator's evaluative stance is quantitatively weaker in the subcorpus for adults (with an average of $61.2 \%$ of sentences in which the evaluative stance of the narrator is present against only $55.6 \%$ in the subcorpus of TTs for teenage/child readership). Although we would perhaps expect the narrator to guide the reader in a more conspicuous and powerfully evaluative way in TTs for teenagers and children, the findings contradict those expectations. This patterning may again be due to the higher degree of condensation shown by TTs for a younger readership and may require a more sophisticated analysis of an aligned parallel corpus.

But let us move on to analyse this evaluative stance that, despite the decrease, still remains predominant in the TTs. 


\section{Attitudinal positioning: positive vs. negative stance (Endorsement vs. Disendorsement)}

The predominantly negative evaluative stance by the narrator in the ST remains predominant in the TTs, too, although all TTs but one tend to decrease it.

Table 7: Attitudinal positioning: positive vs. negative stance (adult readership and teenage/child readership)

\begin{tabular}{|c|c|c|c|c|c|}
\hline & & \multicolumn{2}{|c|}{ \% Positive Stance } & \multicolumn{2}{|c|}{ \% Negative Stance } \\
\hline ST & & \multicolumn{2}{|c|}{22.4} & \multicolumn{2}{|c|}{77.6} \\
\hline \multirow{4}{*}{$\begin{array}{r}\text { TT: } \\
\text { adult reader }\end{array}$} & 1942 & 24.8 & \multirow[t]{4}{*}{24.7} & 75.3 & \multirow[t]{4}{*}{75.3} \\
\hline & 1952 & 29.7 & & 70.3 & \\
\hline & 1980 & 22.4 & & 77.6 & \\
\hline & 1981 & 22.1 & & 78 & \\
\hline \multirow{4}{*}{$\begin{array}{r}\text { TT: } \\
\text { teenage/child } \\
\text { reader }\end{array}$} & 1968 & 26.5 & \multirow[t]{4}{*}{26.6} & 73.5 & \multirow[t]{4}{*}{73.4} \\
\hline & 1972 & 26.9 & & 73.1 & \\
\hline & 1988 & 23.5 & & 76.5 & \\
\hline & 1993 & 29.8 & & 70.2 & \\
\hline
\end{tabular}

Comparing the two translated subcorpora the narrator's negative evaluative stance is on average quantitatively less present in the TTs for teenagers and children (73.4\%) than in TTs for adults $(75.3 \%)$ showing a decrease of $4.2 \%$ and $2.3 \%$, respectively. Only one TT for adults increases the number of sentences that in the ST mark the narrator's negative evaluation. The ratio between positive and negative stance decreases in the translated corpus, which may again be interpreted as a result of the "levelling-out" universal; however, the variable readership profile may motivate a norm governed behaviour that is more strongly felt in the subcorpus for teenagers and children, in which this levelling-out tendency again appears to be stronger.

Therefore, TTs for teenage or child readers show a less negative stance by the narrator than the ST and also a less negative stance by the narrator than TTs for adult readers. Interestingly, this does not correspond to the impression left by reading all target texts, because those for teenagers and children seem more negative in the depiction of characters, actions and places when compared with both the ST and TTs for adult readers. This effect may be explained when we consider whether the evaluative stance of the narrator is marked explicitly or implicitly.

\section{Attitudinal positioning: explicit vs. implicit stance}

A Dickensian narrator is usually associated with irony, because he predominantly implies a negative evaluation by stating the opposite of what 
he means, thus relying heavily on implicature. The latter is retrieved either through the narrator's own contrastive words and sentences or through contrasts between his words and the character's words or actions he chooses to portray. Fairclough mentions "setting" as "the extent to which and ways in which reader/listener interpretation of secondary [quoted] discourse is controlled by placing it in a particular textual context (or 'cotext')" (Fairclough 1995: 60). The control of interpretation through implicature presupposes an addressee competent enough to identify ambivalence and to come to his own conclusions. These conclusions are still controlled by the narrator, but in a subtler way: by offering the narratee (and ultimately the reader) more interpretative leeway, the narrator camouflages his actual power and control that are felt as less forceful. This may posit translational problems and be particularly prone to explicitation and simplification procedures. Especially when the implied readership is teenagers or children, the implied translator's interference is expected to be more strongly felt.

Table 8: Attitudinal positioning: explicit vs. implicit stance (adult readership and teenage/child readership)

\begin{tabular}{|c|c|c|c|c|c|}
\hline & & \multicolumn{2}{|c|}{$\%$ Explicit Stance } & \multicolumn{2}{|c|}{$\%$ Implicit Stance } \\
\hline ST & & \multicolumn{2}{|c|}{12.6} & \multicolumn{2}{|c|}{87.4} \\
\hline \multirow{4}{*}{$\begin{array}{r}\text { TT: } \\
\text { adult reader }\end{array}$} & 1942 & 20.2 & \multirow[t]{4}{*}{15.9} & 79.8 & \multirow[t]{4}{*}{84.1} \\
\hline & 1952 & 13.7 & & 86.3 & \\
\hline & 1980 & 15.4 & & 84.6 & \\
\hline & 1981 & 14.2 & & 85.8 & \\
\hline \multirow{4}{*}{$\begin{array}{r}\text { TT: } \\
\text { teenage/child- } \\
\text { reader }\end{array}$} & 1968 & 41.2 & \multirow[t]{4}{*}{38.2} & 58.8 & \multirow[t]{4}{*}{61.8} \\
\hline & 1972 & 34.4 & & 65.6 & \\
\hline & 1988 & 28.6 & & 71.4 & \\
\hline & 1993 & 48.8 & & 51.2 & \\
\hline
\end{tabular}

As expected, implicit evaluative stance decreases in all TTs analysed, from $87.4 \%$ of sentences in the ST to an average of $72.9 \%$ in all target texts, thus, showing a considerable degree of explicitation, disambiguation and levelling-out. This general tendency is much stronger in TTs for children, where the percentage of implicit evaluative stance decreases to $61.8 \%$, whereas in TTs for adults it is kept at $84.1 \%$, i.e., much closer to the ST's $87.4 \%$. On average, TTs for children show a dramatic $25.6 \%$ decrease of implicit evaluative stance whereas in TT for adults it only decreases $3.3 \%$. Therefore, although narratorial negative stance decreases more strongly in TTs for teenage or child readers, the fact that these TTs seem more sombre appears to be due to explicitation procedures which turn $25.6 \%$ of implicit stance into explicit stance.

Pursuant to our suggestion to posit the existence of an intratextual profile of implied translator, these shifts may be interpreted to draw this profile. The presuppositions of the implied translator regarding a teenage 
reader seem to lead him to expect incapability to interpret implicature by the narrator. Teenage or child TT readers are presupposed to need disambiguation or explicitation procedures, which result from a solidary move by the implied translator to turn implied meaning explicit and thereby accessible. The implied translator's presuppositions regarding adult TT readers differ since these implied TT readers are deemed more competent and are therefore offered the opportunity to judge for themselves, to be surprised and enjoy the (almost) full extent of narratorial irony and humour of implicit negative stance by the narrator. Regarding implicit stance, the Dickensian narrator profile is therefore dramatically different when we compare TTs for adults with those produced for a teenage or child reader.

\section{Final Remarks}

The results of the quantitative analysis presented above may be summarized as follows, regarding each intratextual feature analysed.

- The ST's predominance of dialogue sentences increases in TTs for adults but the opposite happens in TTs for a younger reader, where it decreases.

- $\quad$ The scarce ST's I-Presence of the narrator slightly decreases in most TTs for adults and nearly disappears in TTs for a younger reader.

- $\quad$ The ST's Predominance of Direct Speech decreases in TTs for adults and somewhat more in TTs for teenagers or children

- $\quad$ The ST's Predominance of Evaluative sentences shows an overall decrease that is twice as strong in TTs for a younger audience as in TTs for adults

- The ST's Predominance of Negative Appraisal shows a slight decrease that is stronger in TTs for a younger audience

- As for the ST's Predominance of Implicit Appraisal, it generally decreases, but shows a dramatic decrease of nearly $26 \%$ in TTs for a younger audience.

If we accept these intratextual features as expressive (among others) of the narrator profile, we may conclude that this profile is indeed submitted to transformation in Portuguese translations of Oliver Twist. Explicitation is the procedure that shows the most dramatic counting. Levelling-out procedures are apparent regarding reported speech categories, evaluative vs. neutral stance, positive vs. negative and implicit vs. explicit stance, since the binary analysis carried out shows percentages for opposite categories that become closer in the TT. The only exceptions are forms of selfreference that tend to disappear and the predominance of dialogue reporting sentences in TT for adults.

These procedures are usually accounted for as universals. However, here they have been shown to correlate with the contextual independent 
variable chosen for analysis (target readership age) and are consequently interpreted as a result of translational norms. Shifts are indeed the rule, but they are quantitatively higher in TTs for teenagers and children, where translators appear to grant themselves a stronger power of intervention probably also as a consequence of a higher degree of condensation. Levelling-out appears stronger the higher the degree of condensation. The shifts analysed do not all cohere around a clear and globally identifiable strategy for each translated subcorpus; however, this may be due to the limited dimensions of the corpus under analysis.

There are some other tendencies worth mentioning at this point. TTs for teenage and child readers create a narrator profile that is more audible in terms of the number of dialogue sentences, in terms of selection of reported speech categories, but mostly in terms of explicit stance. In these TTs, narratorial power is stronger regarding these features. This happens because the translator's intervention is also stronger and the number of shifts higher (when compared with TTs for adult readers) since the younger intended reader profile seems to justify a more visible translator that reconfigures the source text for a reader that is deemed less competent. The mediating power of the translator is more strongly felt in a clearly solidary move towards a young reader. In these TTs, the narrator is less evaluative, less negative (than both ST and TT for an adult Reader) and refers less to himself as addresser; this apparently opposite patterning may be attributed to the equally higher degree of condensation shown in these TT.

TTs for adult readers recreate a narrator profile that differs less from that in the ST. These TTs profile a narrator that is less audible because he more often gives the floor to character voices in dialogue, because he is less evaluative and less negative though more explicit than in the ST. One may assume that these shifts, though lower in number and weaker in effect, may be motivated by a consideration of both the TT intended adult reader profile and literary norms in force in the target context, favouring a less audible narrator. Particularly interesting because contrary to the predominant tendency of levelling-out seems to be the increase of the number of dialogue reporting sentences, which renders narratorial power less conspicuous. The higher percentage of dialogue reporting sentences allows the characters' voices to take an even stronger predominance than in the ST since fewer sentences are attributed to the narrator's voice only and the great majority of dialogue reporting resorts to Direct Speech.

In TTs for teenagers and children, the narrator appears more overbearing, more audible and more explicit, also because the implied translator appears more powerful regarding the ST because more solidary (or patronising) towards an intended readership which, because it is deemed less competent, is offered less interpretative leeway. The transformation of the narrator profile is therefore more dramatic in TTs for a younger readership, especially, as the analysis shows, through explicitation of the narrator's favourite discursive strategy of implicature. 
In TT for adult readers the translator's power is less evident, both regarding the ST and the intended readership. However, shifts seem to be motivated by a consideration of a more competent intended reader, both in terms of the inferred capability to interpret implicature and in terms of a presupposed literary competence built by an acquaintance with $20^{\text {th }}$ century literary norms that devaluate an overbearing narrator profile still acceptable in $19^{\text {th }}$ century fiction.

\section{Bibliography}

\section{Primary texts}

\section{Source text}

Dickens, Charles [1837-1839] (1982). Oliver Twist . (Edited by Kathleen Tillotson). Oxford: OUP.

\section{Target texts}

Dickens, Charles [1942]. Oliveiros Twist. (Translation from English). Porto: Livraria Lello \& Irmão. [OT6]

Dickens, Charles (1952). A Estranha História de Oliver Twist. (Translation by Mário Domingues). Lisboa: Romano Torres.[OT7]

Dickens, Charles (1968). Oliver Twist. A história de uma criança a quem a vida martiriza. (Condensation by Raul Correia). Lisboa: Agência Portuguesa de Revistas.[OT8]

Dickens, Charles (1972). Oliver Twist. ( Adaptation by J.M. Carbonell. Translation by Pereira da Silva). Amadora: Livraria Bertrand.[OT9]

Dickens, Charles (1980). Oliver Twist. (Translation revised by R. Correia). Lisboa: Amigos do Livro.[OT13]

Dickens, Charles (1981). Oliver Twist. (Translation by Fernanda Pinto Rodrigues). Mem-Martins: Publicações Europa-América.[OT14]

Dickens, Charles (1988). Oliver Twist. (Version). Lisboa: Círculo de Leitores.[OT16]

Dickens, Charles (1993). Oliver Twist. (Portuguese Version by M. Mendonça Soares). [OT17]

\section{Secondary texts}

Brown, Gillian \& George Yule (1983). Discourse Analysis. Cambridge: Cambridge University Press.

Brown, Penelope \& Stephen C. Levinson[1978] (1987). Politeness. Some Universals in Language Use. Cambridge: Cambridge University Press.

Chatman, Seymour (1978). Story and Discourse: Narrative Structure in Fiction and Film. Ithaca and London: Cornell University Press.

Fairclough, Norman (1995). Critical Discourse Analysis: The Critical Study of Language. London: Longman.

Fludernik, Monika (1993). The Fictions of Language and the Languages of Fiction. London and New York: Routledge.

Genette, Gérard (1972). Figures III. Paris: Éditions du Seuil.

Genette, Gérard (1983). Nouveau Discours du Récit. Paris: Éditions du Seuil.

Grice, H.P. (1975). "Logic and Conversation" P. Cole \& J. Morgan (eds). Syntax and Semantics 3: Speech Acts. . New York: Academic Press.

Gullin, Christina (1998). "Summary”. Översättrens röst. Lund: Lund University Press, 261-266.

Hermans, Theo (1996). "The Translator's Voice in Translated Narrative". Target 8 (1), 23-48.

Hatim, Basil and Ian Mason (1990). Discourse and the Translator. London/New York: Longman.

Leech, Geoffrey N. \& Michael H.Short (1981). Style in Fiction. A Linguistic Introduction to English Fictional Prose. London: Longman.

Marnette, Sophie (1998). Narrateur et Points de Vue dans la Littérature Française Médiévale. Une Approche Linguistique. Bern: Peter Lang. 
McHale, Brian (1978). "Free Indirect Discourse: A Survey of Recent Accounts". Poetics and Theory of Literature 3, 249-287.

O'Sullivan, Emer (2003). "Narratology meets Translation Studies, or, The Voice of the Translator in Children's Literature." Meta 48 (1-2), 197-207.

O'Donnel, Mick. February 2002. Systemic Coder. Version 4.63a. Software.

Page, Norman (1973/1988) . Speech in the English Novel. London: Macmillan.

Rimmon-Kenan, Shlomith (1983). Narrative Fiction: Contemporary Poetics. London/New York: Routledge.

Rosa, Alexandra Assis (1999). "The Centre and the Edges. Linguistic Variation and Subtitling Pygmalion into Portuguese". J. Vandaele (ed.). Translation and the (Re)Location of Meaning. Selected Papers of the CETRA Research Seminars in Translation Studies 19941996. Leuven: CETRA Publications, 317-338.

Rosa, Alexandra Assis (2000). "The Negotiation of Literary Dialogue (Translation). Forms of Address in Robinson Crusoe Translated into Portuguese". Target. 12 (1), 31-62.

Rosa, Alexandra Assis (2001). "Features of Oral and Written Communication in Subtitling".Y.Gambier \& H.Gottlieb (eds). (Multi)Media Translation. Concepts, Practices and Research. Amsterdam: John Benjamins, 213-221.

Rosa, Alexandra Assis (2003). Tradução, Poder e Ideologia. Retórica Interpessoal no Diálogo Narrativo Dickensiano em Português (1950-1999). (Translation, Power and Ideology. Interpersonal Rhetoric in Dickensian Fictional Dialogue Translated into Portuguese 19501999.) PhD Thesis. University of Lisbon.

Rosa, Alexandra Assis (2006). "Defining Target Text Reader. Translation Studies and Literary Theory". J. Ferreira Duarte, A. Assis Rosa \& T. Seruya (eds).. Translation Studies at the Interface of Disciplines. Amsterdam: John Benjamins, 99-109.

Rosa, Alexandra Assis (2007). "Sobre a transformação do perfil do narrador em tradução: marcas linguístico-textuais da intervenção narratorial em ficção" (On the Transformation of Narratorial Profile in Translation: Linguistic-Textual Features of Narratorial Intervention in Fiction). T.Seruya (ed.). Traduções no Coleccionismo Português do século XX. Lisboa: UCP, 131-148.

Rosier, Laurence (1999). Le Discours Rapporté. Histoire, Théories, Pratiques. Paris/Bruxelles: Duculot.

Schiavi, Giuliana (1996). "There is Always a Teller in the Tale". Target 8 (1), 1-21.

Simpson, Paul (1993). Language, Ideology and Point of View. London/New York: Routledge.

Sternberg, Meir (1982). "Proteus in Quotation Land. Mimesis and the Forms of Reported Discourse". Poetics Today 3(2), 107-156.

Toury, Gideon (1995). Descriptive Translation Studies and Beyond. Amsterdam/Philadelphia: John Benjamins.

van Leuven-Zwart, Kitty M. (1989). "Translation and original: similarities and dissimilarities I". Target 1(2), 151-181.

van Leuven-Zwart, Kitty M. (1990). "Translation and original: similarities and dissimilarities II". Target 2(1), 69-95.

White, Peter R. 2001. Guide to Appraisal. Online at: http://www.grammatics.com/appraisal/AppraisalGuide/Framed/Frame.htm. (consulted 20.10. 2006).

${ }^{1}$ The present article focuses on Oliver Twist. However, the methodology was tested in a larger parallel corpus, which also includes Source and Target Texts of A Tale of Two Cities and David Copperfield.

${ }^{2}$ This statement refers to Hermans (1996), Schiavi (1996), and O'Sullivan (2003); a more thorough presentation and discussion of this model can be found in Rosa (2006), who disagrees with O'Sullivan's definition of the implied translator as "the voice of the narrator of the translation", since the implied translator and the narrator are two distinct intratextual participants, located in two different enunciative levels.

${ }^{3}$ Considering the different enunciative levels, so far, our research on tenor in translated fiction has focused on devising a methodology for the semi-automatic analysis of the transactions (1) between the implied translator and the implied TT reader (Addresser and Addressee 2); (2) between 
the narrator and the narratee (Addresser and Addressee 4); and (3) between characters in dialogue (Addresser and Addressee 5). However, the joint consideration of the communicative transaction between all these pairs of participants in translated fiction as well as the time-consuming semiautomatic methodology devised to do so did not allow a more thorough consideration of each one of these pairs of participants in translated fiction as communicative transaction. On the translation of linguistic variation as expressive of tenor in subtitled texts, see Rosa (1999, 2001); on semi-automatic analysis of linguistic variation in translated fiction, see Rosa (2003); on the translation of forms of address as expressive of tenor, see Rosa (2000); on the joint consideration of textual-linguistic features expressive of tenor in the enunciative levels presented by this model, see Rosa (2003).

${ }^{4}$ For the first part of this ongoing research focusing on the translation of narrator-narratee transaction, see Rosa $(2003,2007)$.

${ }^{5}$ The selection and definition of these five categories was based on a comparative analysis of the sets of categories suggested by several authors such as Genette (1972, 1983), Page (1973/1988) Chatman (1978), McHale (1978), Sternberg (1982), Rimmon-Kenan (1983), Fludernik (1993), Simpson (1993) Marnette (1998) and Rosier (1999), but they are mainly based on the categories suggested by Leech and Short's work Style in Fiction (1981: 318-336). For a brief definition of each:

Narrative Report of Speech Acts is the most indirect form of reported speech. The narrator simply mentions the event of a speech act, and the reader assumes that he is not bound to report either content or form of that speech act. It is the category of reported speech in which the narratorial intervention is most visible and least autonomy is conferred to the character's speech.

Indirect Speech quotes the contents of the character's speech, using the narrator's voice, which is also present in the clause containing a verb of saying that accompanies the character's speech. The quoted clause is subordinated to the quoting clause, and the discursive centre that determines personal, temporal and spatial deixis of the reported speech is the narrator.

Free Indirect Speech is a freer version of indirect speech. It can and usually does omit the quoting clause, and markers of the two intervening discursive centres are blended in the quoted clause. It is considerably flexible in terms of which discursive centre determines temporal and spatial deixis. However, personal deixis is determined by the narrator as discursive centre, who uses third person pronouns to refer to the quoted character.

Direct Speech quotes form and content of the character's discourse, and is introduced by a clause containing a verb of saying, the subject of which identifies the author of the reported words. Inverted commas and punctuation signal the juxtaposition of two discursive levels (someone quotes someone else's words). The reported clause is syntactically independent; the discursive centre that determines personal, temporal and spatial deixis is the quoted character's. This category confers considerable autonomy to the quoted character's speech but simultaneously signals the presence and interference of the narrator's voice, in the tag.

Free Direct Speech is even more direct than direct speech. It is defined as a form of direct speech that is devoid of any signals of narratorial intervention. There is no quoting clause, no verb of saying, no punctuation or inverted commas to signal the intervening discursive centres. This is the category of reported speech that confers the greatest autonomy to character speech, since the narrator is invisible.

${ }^{6}$ This semi-automatic analysis involved the creation of classification schemes and the use of the software, Systemic Coder, developed for Discourse Analysis by Mick O’Donnell (2002). 
${ }^{7}$ This is what Fairclough (1995: 60) identifies as "representing the illocutionary force of the secondary discourse." Within the current predominant ideological context, the choice of "order" as a very explicit expression of actual power will probably be interpreted negatively. The implied translator's shift from ST "said" to TT "ordered" may even be interpreted as denouncing the quotee, Mrs. Sowerberry, as a bully and thereby controlling the implied reader's response. On the other hand, it may also be interpreted as a marker of solidarity with the teenage/child implied reader, whose positioning may be anticipated in this choice of "ordered" (see Fairclough 1995: 62). Whether this shift is attributable to the Portuguese interlingual translator or to the intralingual translator who produced the English language version used as ST is yet another line of inquiry that can be followed in future research.

${ }^{8}$ As stated by Brown and Yule (1983: 31): "The term 'implicature' is used by Grice (1975) to account for what a speaker can imply, suggest or mean, as distinct from what the speaker literally says." As Brown and Levinson also suggest ([1978] 1987: 57) indirect expressions, equated with implicature, also tend to be used to express criticism, as is the case of negative evaluative and implicit stance so often characteristic of Dickensian narrators.

9 Based on White (2001), we suggest a set of descriptive categories for the study of source and target texts focussing on the relationship between the two discursive centres involved in reported speech, expressed in terms of (1) Endorsement, defined as an evaluative stance that can either be classified as (1a) Endorsement, if the narrator evaluates positively what he quotes, or (1b) Disendorsement, if the narrator evaluates negatively what he quotes; or (2) neutral, if no type of evaluation can be ascertained from the analysis.

${ }^{10}$ Translation is here interpreted in the broad sense, all target text versions were included, irrespective of their labels ('translation', 'full text translation', 'adaptation' or 'condensation').

${ }^{11}$ The degree of condensation of these TT versions was assessed by comparing the number of sentences in the ST with the number of sentences in each TT regarding the same four initial chapters. In this corpus, TTs for adult readership recreate on average $91.41 \%$ of ST sentences whereas TTs for teenagers or children condensate more and recreate on average $40.42 \%$ of the number of ST sentences.

${ }^{12}$ Against this predominant background, the increase of DS and FDS in the seventies and eighties, that is the increase in forms that make the narrator's power and control less visible (in one text for adults published in 1980 and one text for teenagers published in 1972), becomes noteworthy. Despite this verification for the seventies and early eighties, these results to not correlate very consistently either with date of publication or with the degree of condensation. It is very often the case that coherence is lacking when we analyse translation but this may also be due to the restricted scope of this corpus and calls for further studies. 